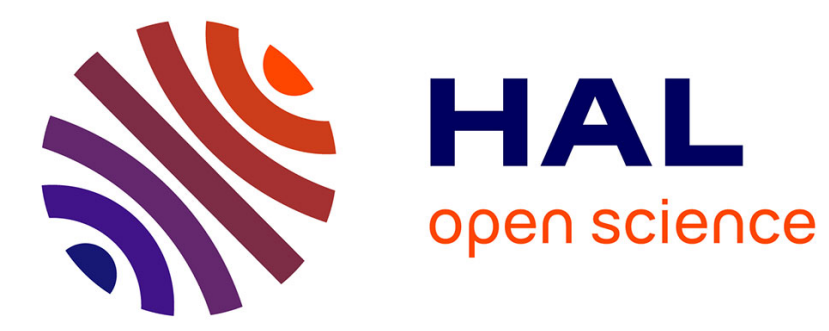

\title{
Intra-and interspecific competition differently influence growth and stem quality of young oaks (Quercus robur L. and Quercus petraea (Mattuschka) Liebl.)
} Somidh Saha, Christian Kuehne, Jürgen Bauhus

\section{- To cite this version:}

Somidh Saha, Christian Kuehne, Jürgen Bauhus. Intra-and interspecific competition differently influence growth and stem quality of young oaks (Quercus robur L. and Quercus petraea (Mattuschka) Liebl.). Annals of Forest Science, 2014, 71 (3), pp.381-393. 10.1007/s13595-013-0345-1 . hal01101537

\author{
HAL Id: hal-01101537 \\ https://hal.science/hal-01101537
}

Submitted on 8 Jan 2015

HAL is a multi-disciplinary open access archive for the deposit and dissemination of scientific research documents, whether they are published or not. The documents may come from teaching and research institutions in France or abroad, or from public or private research centers.
L'archive ouverte pluridisciplinaire HAL, est destinée au dépôt et à la diffusion de documents scientifiques de niveau recherche, publiés ou non, émanant des établissements d'enseignement et de recherche français ou étrangers, des laboratoires publics ou privés. 


\title{
Intra- and interspecific competition differently influence growth and stem quality of young oaks (Quercus robur $\mathbf{L}$. and Quercus petraea (Mattuschka) Liebl.)
}

\author{
Somidh Saha $\cdot$ Christian Kuehne $\cdot$ Jürgen Bauhus
}

Received: 22 July 2013 / Accepted: 11 November 2013 /Published online: 17 December 2013

(C) INRA and Springer-Verlag France 2013

\begin{abstract}
- Context Cluster planting has become a conventional establishment method for oaks in Central Europe, where the spacing of seedlings within clusters varies between 'nests' $(0.2 \times 0.2 \mathrm{~m})$ and 'groups' $(1 \times 1 \mathrm{~m})$. Although the space between clusters is expected to fill with voluntary regeneration, its competitive effect on oak growth and quality had not been studied yet.

- Aims The aim of the study was to analyse the effects of inter- and intraspecific interactions on growth and quality of oaks grown in cluster plantings by quantifying the influence of neighbouring trees. In addition, we analysed whether the spatial position of oaks within groups (inner section or periphery) influenced their quality development.

- Methods Using Hegyi's competition index, the influence of competition from intra- and interspecific trees from early, midand late-successional species, on diameter, height, slenderness and quality (length of branch-free bole) of 10- to 26-year-old

Handling Editor: Jean-Michel Leban

Contribution of the co-authors Somidh Saha and Jürgen Bauhus jointly developed the research concept and experimental design. Jürgen Bauhus provided doctoral supervision to the first author. Somidh Saha carried out the field work and did all statistical analysis. Somidh Saha, Christian Kuehne and Jürgen Bauhus wrote the manuscript. Christian Kuehne also participated in field data collection. Parts of the results in relation to the first hypothesis were presented as a poster at the German Forestry conference: 'Forest-Climate-Energy' (Forstwissenschaftlichen Tagung, 'Wald-Umwelt-Energie'), at Weihenstephan, Germany, from 19 to 22 September 2012. However, only the abstract (ca. 200 words) was published in the conference proceeding.
\end{abstract}

S. Saha $(\bowtie) \cdot$ C. Kuehne $\cdot$ J. Bauhus

Chair of Silviculture, Faculty of Environment and Natural Resources,

Albert Ludwigs University of Freiburg, Tennenbacherstr. 4,

79085 Freiburg, Germany

e-mail: somidh.saha@waldbau.uni-freiburg.de

S. Saha

e-mail: somidhs@gmail.com oaks grown in cluster planting stands was quantified at seven sites in Baden-Württemberg and Hessen, Germany.

- Results In general, mid- and late-successional trees exerted a stronger competitive influence on growth of target oaks in clusters than the conspecific oaks and pioneer tree species. Oak quality development benefited from intraspecific competition, but self-pruning was not further promoted through additional interspecific competition. Within groups, inner oaks had a higher probability of developing into potential future crop trees than outer oaks.

- Conclusion Our study showed that intra- and interspecific competition had different effects on target oak trees and that these effect differed between nest and group plantings. The development of naturally regenerated and planted trainer trees in group plantings should be monitored carefully and if necessary be controlled through thinning or pollarding.

Keywords Intraspecific competition · Interspecific competition · Facilitation · Stem quality · Cluster planting · Generalized linear models

\section{Introduction}

Traditional reforestation methods aim to achieve full site occupancy at an early stage of stand development through the planting of a sufficient number of individuals of the desired tree species (Drouineau et al. 2000). However, this conventional approach has a few disadvantages including high costs for site preparation, plants and planting (Gockel 1995; Ehring and Keller 2006). In addition, the resulting early stand development phases often lack typical post-disturbance characteristics such as highly diverse early successional vegetation leading to complex food webs and residual structures (Swanson et al. 2010). Therefore, low-input reforestation 
methods have been developed that combine a reduced number of planted target tree species per hectare with natural regeneration in the remaining area (Drouineau et al. 2000). Cluster planting is an example of low-input planting designs aiming to save planting costs, promote natural succession of other species as well as foster development of high-quality hardwood trees in young stands (Saha et al. 2012, 2013). The planting of oaks in widely spaced clusters using ca. 2,100-4,200 seedlings $\mathrm{ha}^{-1}$ was introduced in Central Europe in the 1980s and 1990s as an alternative to traditional row planting, which used higher seedling densities of 5,000-10,000 ha ${ }^{-1}$. Oak clusters have been classified as 'nests' (nest planting) or 'groups' (group planting) that consist of 20-30 seedlings planted in an aggregated manner with 0.2 or $1 \mathrm{~m}^{2}$ initial spacing and approximately 200 or 100 such uniformly distributed clusters per hectare, respectively (Gockel 1995; Szymanski 1986). However, the initial number of clusters per hectare and seedlings planted per clusters varied across nest (150-200 nests ha ${ }^{-1}$ ) and group (70-100 groups $\mathrm{ha}^{-1}$ ) planting trials established in Central Europe (Brang and Bürgi 2004; Saha et al. 2012, 2013). Trainer trees from shade-tolerant species such as Carpinus betulus L., Tilia cordata Mill. and Fagus sylvatica L. are commonly planted at varying densities at the periphery of the oak groups, although this was not done for the nest plantings analysed in this study. The spaces left unplanted between clusters are usually occupied by natural regeneration of woody plants, often of early, mid and late-successional tree species. These may increase tree species richness and contribute significantly to stand productivity (Saha 2012; Saha et al. 2013).

Conventional management of oaks for high-quality timber aims at crown closure of stands within 10-15 years after establishment to promote intraspecific competition and thus self-pruning of trees (Röhrig et al. 2006). For a fully stocked oak stand, a typical silvicultural goal is to produce 60-80 crop trees $\mathrm{ha}^{-1}$ at the end of the production cycle, which may be reached after 130 to 180 years depending on site productivity. These should be vigorous trees that have a branch-free bole of ca. 8-10 $\mathrm{m}$ and a straight stem and be fairly evenly spaced (von Lüpke 1998). Whether this goal can be achieved with the cluster planting design may be questioned for two reasons. Firstly, the natural regeneration of other tree species occurring between clusters may grow faster than oaks and pose strong competition to oaks, thus reducing the probability that vigorous oaks develop within clusters. Secondly, quality development of oak stems may not proceed as desired, if there is significant variability in crown closure and hence competition between neighbouring trees. For example, if trees between clusters regenerate much later, only sparsely, or grow substantially slower, self-pruning of oaks in clusters, in particular of trees in the perimeter of clusters, may be delayed (Guericke et al. 2008; Leder 2007; Petersen 2007). The early proponents of cluster planting assumed that the protection of inner oaks by outer oaks from interspecific competition and browsing would facilitate inner oaks to develop into potential future crop trees (Szymanski 1986; Gockel 1995). Recent findings on the importance of interspecific competition confirm this hypothesis (Saha et al. 2012). It has also been suggested that there must be enough interspecific competition from naturally established trees between the clusters to ensure that the oak trees self-prune and thereby improve quality (Dong et al. 2007). These assumptions, however, were never tested, and the effects of naturally regenerated and planted trainer and conspecific trees on the development of oaks established and grown in clusters have not been quantitatively evaluated.

Previous studies on the effect of fast-growing broadleaved tree species (e.g. Betula pendula Roth, Populus spp., Salix spp.) on diameter and height growth as well as on stem quality of oaks in conventional stands established by row planting yielded contradictory results (Rock et al. 2004). In the majority of these studies, competition was not quantified, and moreover, intra- and interspecific interactions were not separated (Ammer and Dingel 1997; Petersen et al. 2009; Rock et al. 2004). Therefore, we aimed to analyse the effects of intra- and interspecific interactions on growth and quality of oaks grown in cluster plantings by quantifying the competitive influence of neighbouring trees. Specifically, we aimed to test the following hypotheses:

1. The effect on growth of young oaks in nest and group plantings differs between competitive influences exerted (a) intraspecifically by other oaks and (b) interspecifically by pioneers (early successional tree species) and (c) midand late-successional tree species.

2. Intra- and interspecific competition does not differ in their influences on quality development (measured as branchfree bole length) of young oaks grown in cluster plantings.

3. Quality development of oaks in the inner part of groups is superior compared to that at the perimeter. Inner oaks therefore have a higher probability of emerging as potential future crop trees.

\section{Materials and methods}

\subsection{Study sites}

Seven locations with stands established as group or nest plantings of oak (Quercus robur and Quercus petraea) were sampled in Baden-Württemberg and Hesse, Germany (Table 1). Mean annual temperature and rainfall vary among these sites between 6.5 and $10.2{ }^{\circ} \mathrm{C}$ and $670-832 \mathrm{~mm}$, respectively, with the majority of precipitation occurring in the growing season between May and September (Gauer and Aldinger 2005). The dominant soil type across study sites is a stagnosol originating from basalt loam, silt stone or sandstone, with the exception of 
Table 1 Location of study sites in Germany and their site characteristics. Mean annual volume increment of oaks is averaged for the period 0-100 years and determined with yield tables. Ecoregions (German
'Wuchsgebiete') follow the classification of the German Society of Forest Site Classification and Forest Growth (modified from Gauer and Aldinger 2005)

\begin{tabular}{|c|c|c|c|c|c|c|c|}
\hline Sites & $\begin{array}{l}\text { Location (name of the } \\
\text { nearest town and state) }\end{array}$ & Ecoregion & $\begin{array}{l}\text { Elevation } \\
\text { m a.s.l. }\end{array}$ & $\begin{array}{l}\text { Mean } \\
\text { annual } \\
\text { temp. } \\
\left({ }^{\circ} \mathrm{C}\right)\end{array}$ & $\begin{array}{l}\text { Mean } \\
\text { annual } \\
\text { rainfall } \\
(\mathrm{mm})\end{array}$ & Soil types & $\begin{array}{l}\text { Mean annual } \\
\text { oak volume } \\
\text { increment } \\
\left(\mathrm{m}^{3} \mathrm{ha}^{-1} \text { year }^{-1}\right)\end{array}$ \\
\hline Altenheim & Lahr, Baden-Württemberg & Upper Rhine valley & 143 & 10.2 & 832 & Gleyic cambisol & 8 \\
\hline Gerlingen & Stuttgart, Baden-Württemberg & Neckar River basin & 440 & 8.1 & 780 & Stagnogleyic cambisol & 7.5 \\
\hline Gerchsheim & $\begin{array}{l}\text { Tauberbischofsheim, } \\
\text { Baden-Württemberg }\end{array}$ & Franconian plateau & 310 & 8.5 & 670 & Stagnogleyic cambisol & 8 \\
\hline Kaisereiche & Schwarzenborn, Hessen & Northwest Hessian mountain & 550 & 6.5 & 800 & Stagnogleyic cambisol & 8 \\
\hline Königheim & $\begin{array}{l}\text { Tauberbischofsheim, } \\
\text { Baden-Württemberg }\end{array}$ & Neckar River basin & 380 & 8.1 & 750 & Cambisol & 8.5 \\
\hline Lerchenfeld & Schwarzenborn, Hessen & Northwest Hessian mountain & 550 & 6.5 & 800 & Stagnogleyic cambisol & 8 \\
\hline Leonberg & Stuttgart, Baden-Württemberg & Neckar River basin & 420 & 8.5 & 780 & Stagnogleyic cambisol & 7.5 \\
\hline
\end{tabular}

Altenheim (gleyic cambisol), originating from alluvial deposits covered by a layer of loess. The resulting site conditions provide for moderate growth rates of oak, which are according to yield tables equivalent to a mean annual increment of 7.5$8.5 \mathrm{~m}^{3} \mathrm{ha}^{-1}$ year ${ }^{-1}$ over a 100 -year rotation (Table 1).

On average, the area of each inventoried stand was about 1 ha. Reforestation with oaks took place between 1986 and 2000 after previous stands of mainly coniferous species (Picea abies (L.) H. Karst., Pseudotsuga menziesii (Mirb.) Franco) were uprooted by storms or clear-felled. Manual site preparation prior to planting was restricted to patches where the oak clusters were planted. As part of the basic planting design, a varying number of trainer trees were planted around oak groups (Table 2).

The stands were fenced off during the very first years after establishment to avoid browsing of seedlings. All reforestations were adjacent to existing forests, usually mature mixed oak as well as mixed and pure conifer stands. Few naturally established pioneer, mid and late-successional trees were removed once in stands at Gerlingen and Lerchenfeld 5-8 years after planting. However, those tending operations were only carried out in the periphery of clusters and tree species were not preselected before removal. No tending operations were carried out at other sites. Nevertheless, at the time of our inventory, when stands were 20-26 years old, pioneer as well as mid- and late-successional species were abundant, which may be partially attributable to coppicing of the removed trees. In the younger stand of Altenheim, which is located in a moist site close to the river Rhine, abundant natural regeneration of mid- and late-successional species of Acer pseudoplatanus L. and C. betulus were found (Saha 2012; Saha et al. 2013). Mean height and diameter at $1.3 \mathrm{~m}(\mathrm{DBH})$ of oaks grown in cluster plantings ranged between $6-9.5 \mathrm{~m}$ and 5-11.5 cm, respectively, and the length of the branch-free bole varied from 3.3 to $4.6 \mathrm{~m}$ (Tables 3 and 4).

\subsection{Sampling design and data collection}

We established systematic inventory strips along rows of nests or groups to cover at least one third of the area of each stand. Strips were not established at the boundaries of stands to avoid edge effects, skidding trails and forest roads. Within inventory strips, we measured DBH of all oaks and trainer trees and recorded stem form and crown type of all cluster oaks in the summers of 2010 and 2011. We used a morphological classification for the assessment of stem form and crown shape as proposed by Börner et al. 2003 and used by Kuehne et al. 2013, Saha et al. 2012 for young oaks. Stand-specific height curves for every species based on DBH were developed to calculate tree height of all individual trees. We calculated tree height to $\mathrm{DBH}$ ratio (height-to-diameter (HD) ratio) as an indicator of individual tree stability. High HD ratios indicate poor physical tree stability, which is relevant for young oaks in situations of snow load. Vigorous, dominant or co-dominant oaks with straight stems and monopodial crowns were classed as potential future crop trees and served as target trees for the competition analysis. In case of multiple potential future crop trees per nest or group, all were considered as target trees in the competition analysis. At fertile sites, dominant and codominant trees would exert higher competitive pressure on target trees than suppressed trees due to size asymmetric competition for light (Pretzsch and Biber 2010). Based on this assumption, trees with heights equal or greater than two thirds of the respective target tree were selected as competitors in a circle with a radius of $3 \mathrm{~m}$ around target trees. Species identity, distance, and DBH of each competitor within that circle were recorded. Apart from intraspecific competitors (oaks), all other competing trees were classified into two broad groups based on their occurrences in successional dynamics: (a) pioneers, which included early successional species (B. pendula, Salix caprea L., Salix alba L., Populus tremula L., Pinus sylvestris L., and 
Table 2 Design characteristics of cluster planting sites. Average size of the studied stands was 1 ha. No trainer trees were planted inside nests. Note, the initial spacing between seedlings vary significantly between the nests and groups but not within the cluster type

\begin{tabular}{|c|c|c|c|c|c|c|c|}
\hline Location & Altenheim & Gerlingen & Gerchsheim & Kaisereiche & Königheim & Lerchenfeld & Leonberg \\
\hline Cluster type & Group & Nest & Nest & Group & Nest & Group & Nest \\
\hline Oak species planted & Quercus robur & Quercus robur & Quercus robur & Quercus petraea & Quercus petraea & Quercus petraea & Quercus robur \\
\hline Age & 10 & 26 & 22 & 20 & 22 & 20 & 23 \\
\hline $\begin{array}{l}\text { Spacing between oaks } \\
\text { in cluster }(\mathrm{m})\end{array}$ & $1 \times 1$ & $0.3 \times 0.3$ & $0.25 \times 0.25$ & $1 \times 1$ & $0.25 \times 0.25$ & $1 \times 1$ & $0.3 \times 0.3$ \\
\hline Clusters ha ${ }^{-1}$ & 70 & 180 & 200 & 100 & 200 & 100 & 150 \\
\hline Oaks cluster $^{-1}$ & 19 & 21 & 21 & 27 & 21 & 27 & 21 \\
\hline Trainers cluster $^{-1}$ & 12 & & & 15 & & 15 & \\
\hline Trainer species & $\begin{array}{l}\text { Tilia cordata, } \\
\text { Carpinus } \\
\text { betulus }\end{array}$ & & & Fagus sylvatica & & Fagus sylvatica & \\
\hline
\end{tabular}

Sorbus aucuparia L.) and (b) mid- and late-successional species (Fraxinus excelsior L., A. pseudoplatanus, Acer platanoides L., P. abies (L.) H. Karst., P. menziesii (Mirb.) Franco, C. betulus, T. cordata and F. sylvatica). In addition to successional status, these species groups differ in their shade tolerance and, hence, in their ability to cast shade, which is higher in the latter group (Tonioli et al. 2001; McLeod et al. 2001). We finally combined intra- and interspecific competition to calculate aggregate competition, which was the total amount of neighbourhood competition exerted on target trees. To

Table 3 Mean DBH and height of oaks growing in cluster planting stands

\begin{tabular}{|c|c|c|c|c|c|c|c|}
\hline Site & $\begin{array}{l}\mathrm{DBH} \\
\text { mean } \\
(\mathrm{cm})\end{array}$ & S.E. & $N$ & $\begin{array}{l}\text { Height } \\
\text { mean } \\
(\mathrm{m})\end{array}$ & S.E. & $N$ & $\begin{array}{l}\text { Stand } \\
\text { age } \\
\text { (year) }\end{array}$ \\
\hline Altenheim & & & & & & & 10 \\
\hline Inner oaks & 5.11 & 0.17 & 133 & 6.68 & 0.09 & 133 & \\
\hline Peripheral oaks & 5.69 & 0.13 & 225 & 6.99 & 0.07 & 225 & \\
\hline $\begin{array}{l}\text { All (inner }+ \\
\text { peripheral oaks) }\end{array}$ & 5.47 & 0.1 & 358 & 6.88 & 0.05 & 358 & \\
\hline Kaisereiche & & & & & & & 20 \\
\hline Inner oaks & 5.57 & 0.19 & 178 & 4.78 & 0.23 & 105 & \\
\hline Peripheral oaks & 6.13 & 0.45 & 202 & 5.97 & 0.9 & 122 & \\
\hline $\begin{array}{l}\text { All (inner }+ \\
\text { peripheral oaks) }\end{array}$ & 5.87 & 0.26 & 380 & 5.42 & 0.5 & 227 & \\
\hline Lerchenfeld & & & & & & & 20 \\
\hline Inner oaks & 7.88 & 0.26 & 148 & 6.95 & 0.32 & 140 & \\
\hline Peripheral oaks & 9.26 & 0.23 & 230 & 8.7 & 0.28 & 223 & \\
\hline $\begin{array}{l}\text { All (inner }+ \\
\text { peripheral oaks) }\end{array}$ & 8.72 & 0.18 & 378 & 8.02 & 0.22 & 363 & \\
\hline Gerlingen & 11.67 & 0.36 & 169 & 9.37 & 0.14 & 169 & 26 \\
\hline Gerchsheim & 7.28 & 0.26 & 236 & 8.71 & 0.15 & 236 & 22 \\
\hline Königheim & 6.58 & 0.18 & 472 & 8.05 & 0.13 & 472 & 22 \\
\hline Leonberg & 7.01 & 0.14 & 460 & 8.34 & 0.08 & 460 & 23 \\
\hline
\end{tabular}

S.E. standard error, $N$ number of oaks inventoried quantify competition intensity, Hegyi's competition index was calculated (Hegyi 1974). Hegyi's index has been successfully used to quantify tree competition and has proved to be as suitable as other height- and crown-based indices in young, mixed broadleaved stands in Germany (Ammer et al. 2005).

Testing of the third hypothesis was restricted to group plantings, since the original location of oaks within nests could not be determined owing to high mortality rates. To address the third hypothesis, we used all oaks inventoried in the group plantings, which were divided into 'inner oaks' and 'outer oaks' (Saha et al. 2013).

\subsection{Statistical analysis}

For the first and second hypothesis, we analysed the influence of competition (aggregate and intra- and interspecific competition exerted by different tree groups) on $\mathrm{DBH}$, height, $\mathrm{HD}$ ratio and branch-free bole length of target oaks. Since there may be interactions between these three types of competition, we did not use one additive model to test for their effects on target oaks. First, we calculated the overall impact from aggregate competition on these variables (Eq. 1). Here, we included all competitors irrespective of their species to test the impact of total neighbourhood competition on target oaks from tree species groups classified based on their successional status. Then, we separately calculated the impacts of competition from different tree species groups (Eq. 2). For this purpose, we built interaction terms between the tree species groups to identify interactive effects on target oaks. We used generalized linear models (GLMs) to study the effects of competition on DBH, height, HD ratio and branch-free bole length of target oaks. We chose the GLM approach for our analysis because it permits fitting of linear models to any distribution function included in the exponential family by performing maximum likelihood analysis (McCullagh and Nelder 1989). Fitting tree height and DBH to exponential and power functions have been shown to be a biologically sound approach for age-independent models when 
Table 4 Mean DBH, height and branch-free bole length of target oaks and competing trees from pioneer, mid- to late-successional species or oaks. DBH of competing trees did not vary significantly between different groups of competing species (independent sample $t$ test with bootstrap re-sampling and 10,000 iterations)

\begin{tabular}{|c|c|c|c|c|c|c|c|c|c|c|c|c|c|c|c|c|c|c|}
\hline \multirow[t]{3}{*}{ Site } & \multirow[t]{3}{*}{ Cluster type } & \multicolumn{8}{|c|}{ Target oak trees } & \multicolumn{3}{|c|}{$\begin{array}{l}\text { Competing } \\
\text { pioneer species }\end{array}$} & \multicolumn{3}{|c|}{$\begin{array}{l}\text { Competing } \\
\text { mid- and late- } \\
\text { successional } \\
\text { species }\end{array}$} & \multicolumn{3}{|c|}{$\begin{array}{l}\text { Competing oaks } \\
\text { (intraspecific) }\end{array}$} \\
\hline & & \multicolumn{2}{|c|}{ DBH (cm) } & \multicolumn{2}{|c|}{ Height (m) } & \multicolumn{4}{|c|}{ Branch-free bole length (m) } & \multicolumn{3}{|c|}{$\mathrm{DBH}(\mathrm{cm})$} & \multicolumn{3}{|c|}{ DBH $(\mathrm{cm})$} & \multicolumn{3}{|c|}{$\mathrm{DBH}(\mathrm{cm})$} \\
\hline & & Mean & S.E. & Mean & S.E. & Mean & S.E. & $N$ & $\begin{array}{l}\% \text { of } \\
\text { total } \\
\text { height }\end{array}$ & Mean & S.E. & $N$ & Mean & S.E. & $N$ & Mean & S.E. & $N$ \\
\hline Altenheim & Group & 7.84 & 0.3 & 7.97 & 0.11 & 3.7 & 0.14 & 28 & 46 & n.a. & n.a. & n.a. & 6.10 & 0.15 & 210 & 6.22 & 0.16 & 190 \\
\hline Kaisereiche & Group & 8.48 & 0.61 & 6.75 & 0.71 & 4.61 & 0.28 & 24 & 68 & 8.38 & 0.8 & 29 & 9.03 & 0.58 & 33 & 7.32 & 0.18 & 117 \\
\hline Lerchenfeld & Group & 10.84 & 0.47 & 10.45 & 0.6 & 4.62 & 0.23 & 25 & 44 & 9.22 & 0.5 & 55 & 11 & 2.93 & 3 & 9.88 & 0.24 & 159 \\
\hline Gerlingen & Nest & 13.48 & 0.62 & 10.09 & 0.18 & 3.3 & 0.19 & 50 & 33 & 11.69 & 0.88 & 24 & 9.97 & 0.67 & 19 & 12.25 & 0.39 & 97 \\
\hline Gerchsheim & Nest & 10.33 & 0.54 & 10.37 & 0.18 & 4.21 & 0.2 & 35 & 41 & 11.83 & 0.97 & 18 & 13.7 & 1 & 28 & 9.33 & 0.29 & 103 \\
\hline Königheim & Nest & 9.71 & 0.39 & 10.42 & 0.19 & 3.93 & 0.24 & 40 & 38 & 8.17 & 0.99 & 9 & 11.72 & 2.01 & 18 & 9.23 & 0.25 & 172 \\
\hline Leonberg & Nest & 9.18 & 0.29 & 9.58 & 0.12 & 4.22 & 0.26 & 55 & 44 & 8.05 & 0.46 & 49 & 8.21 & 0.29 & 112 & 8.58 & 0.18 & 209 \\
\hline
\end{tabular}

S.E. standard error, $N$ number of target oaks and competitors in each cluster planting stand, n.a. not available

variability in outcomes among these variables can be expected in forest stands (Wykoff 1990; Gea-Izquierdo et al. 2008). GLM directly fit the expected mean of the dependent variable, hence avoiding the biases for transformed (e.g. log-transformed) linear models (McCullagh and Nelder 1989). In competition analyses, the structure of GLMs was as follows:

$$
\begin{aligned}
E\left(Y_{i}\right)= & \mu_{i}=g^{-1}\left(\beta_{0} \times \text { Aggregate competition }\right) \\
E\left(Y_{i}\right)= & \mu_{i}=g^{-1}\left(\beta_{1} \times\right. \text { Intraspecific competition } \\
& +\beta_{2} \times \text { Competition from pioneer trees } \\
& \left.+\beta_{3} \times \text { Competition from mid-and late-successional trees }\right)
\end{aligned}
$$

where $Y_{i}$ was the random component or dependent variable (belonging to the exponential family of Gaussian distributions), $E\left(Y_{i}\right)$ is the expected value for $Y_{i}, \mu_{i}$ is the mean of the distribution from the dependent variable, $g^{-1}$ being the link function (in our case, an identity function with Gaussian distribution), and $\beta_{0} \beta_{1} \beta_{2}$ and $\beta_{3}$ were the estimates of competition. These estimates were treated as the magnitude of competitive effects, which were calculated by maximum likelihood methods and tested for statistical significance by Wald chisquare tests. The $95 \%$ Wald confidence interval was calculated for each estimate. For a significant effect, confidence interval of a parameter estimate should not touch the zero line. By using Spearman's rank correlation test, we also tested whether an absolute value of intraspecific competition changes with an increase in interspecific competition across all seven study sites.

For the third hypothesis, we carried out separate analyses to find changes in the competitive influence on oaks located in inner or peripheral part of groups. Binary logistic regression was used to test the influence of tree position in groups (inner section or periphery) on the occurrence of potential future crop trees. The occurrence of potential future crop trees were estimated by using an effect size called odds ratio. The odds ratio (log transformed) is the ratio of the odds of an event (the presence or absence of potential future crop tree) occurring in one category (e.g. inner section of groups) to the odds of it occurring in another category (e.g. periphery of groups). The values of odds ratio were converted to percentage for getting the rate of occurrences. Another GLM analysis was used to test for the influence of competitive interactions between the type of competition (intra- or interspecific) and the target tree location on the branch-free bole length. Comparisons between the mean $\mathrm{DBH}$ and the height of target oaks and competitors of different successional groups were performed by independent sample $t$ tests. As the number of target oaks and competitors inevitably differed, we performed $t$ test with bootstrap re-sampling (10,000 iterations). We used the R 2.14.0 open-source statistical programme for analysis (R Development Core Team 2011).

\section{Results}

3.1 Influence of competition on $\mathrm{DBH}$, height, HD ratio and branch-free bole length of target trees

\subsubsection{Nest planting}

In the four nest planting stands, each target oak had on average two competing trees from either pioneer or mid- and late- 
successional species and four competing oaks (Fig. 1). The average DBH of target oaks was significantly higher $(p<0.05)$ than in competing oaks. However, DBH did not differ significantly $(p>0.05)$ between target oaks and interspecific competitors. Interestingly, DBH did not vary significantly $(p>0.05)$ between pioneers and mid- and late-successional competitors across four nest planting stands. Similarly, DBH did not vary significantly between competing trees belonging either to conspecific oaks or pioneer or mid- and latesuccessional species $(p>0.05)$ (Table 4$)$. The average distance between target trees and competing oaks was about $1 \mathrm{~m}$. Competitors of pioneer as well as mid- and late-successional trees were located on average 2.08 and $2.18 \mathrm{~m}$ from target oak trees, respectively (Table 5).

Aggregate competition from surrounding trees strongly affected DBH and HD ratio of target oaks in the nest plantings. Interspecific competition from mid- and late-successional species had a stronger effect than intraspecific competition. Height of target oaks was neither affected by intraspecific nor interspecific competition (Fig. 2). In contrast, intraspecific competition significantly increased the length of the branchfree bole, whereas interspecific competition had no effect on this parameter of tree quality (Fig. 2).

\subsubsection{Group planting}

On average, each target oak was surrounded by two competing pioneers, one competing tree of mid- and late-successional species and six competing oaks in the group planting stands at Kaisereiche and Lerchenfeld (Fig. 1). Competition from pioneer species was absent at Altenheim, but target oaks were surrounded by eight competitors from mid- and late- successional species as well as six planted oaks (14 competing trees in total). In Altenheim, DBH was significantly higher in target trees than in conspecific oaks and in mid- and latesuccessional competitors. However, it did not vary significantly $(p>0.05)$ between competing oaks and mid- and latesuccessional trees. In contrast, in Kaisereiche and Lerchenfeld, average DBH of target oaks did not differ significantly $(p>0.05)$ from that of pioneer and mid- and late-successional trees. No significant differences $(p>0.05)$ were found in tree DBH between pioneer and mid- and late-successional trees (Table 4). The average distance between target oak trees and other competing oaks within clusters was $1.81 \mathrm{~m}$. Competitors of both pioneer and mid- and late-successional tree species were on average located at 2.09 and $2.14 \mathrm{~m}$ distance from target oak trees, respectively (Table 5).

Height, DBH and HD ratio of target oaks were negatively influenced by aggregate competition from surrounding trees (Fig. 3a, b). Intraspecific competition significantly reduced DBH and height growth of oaks in the 10-year-old Altenheim group planting. Competition from mid- and late-successional trees, however, had no significant influence. The HD ratio significantly increased with aggregate and intraspecific competition. However, interspecific competition had no significant effect on the HD ratio and, hence, tree stability in Altenheim. In that stand, aggregate competition was positively related to the branch-free bole length; however, intra- or interspecific competition had no significant effect (Fig. 3a). The observed interaction pattern changed in the two 20-yearold group planting stands at Kaisereiche and Lerchenfeld. Here, intraspecific competition had clearly no significant effect on DBH and height, whereas this may not be excluded for pioneer trees $(p=0.0649$ for DBH). In contrast, competition
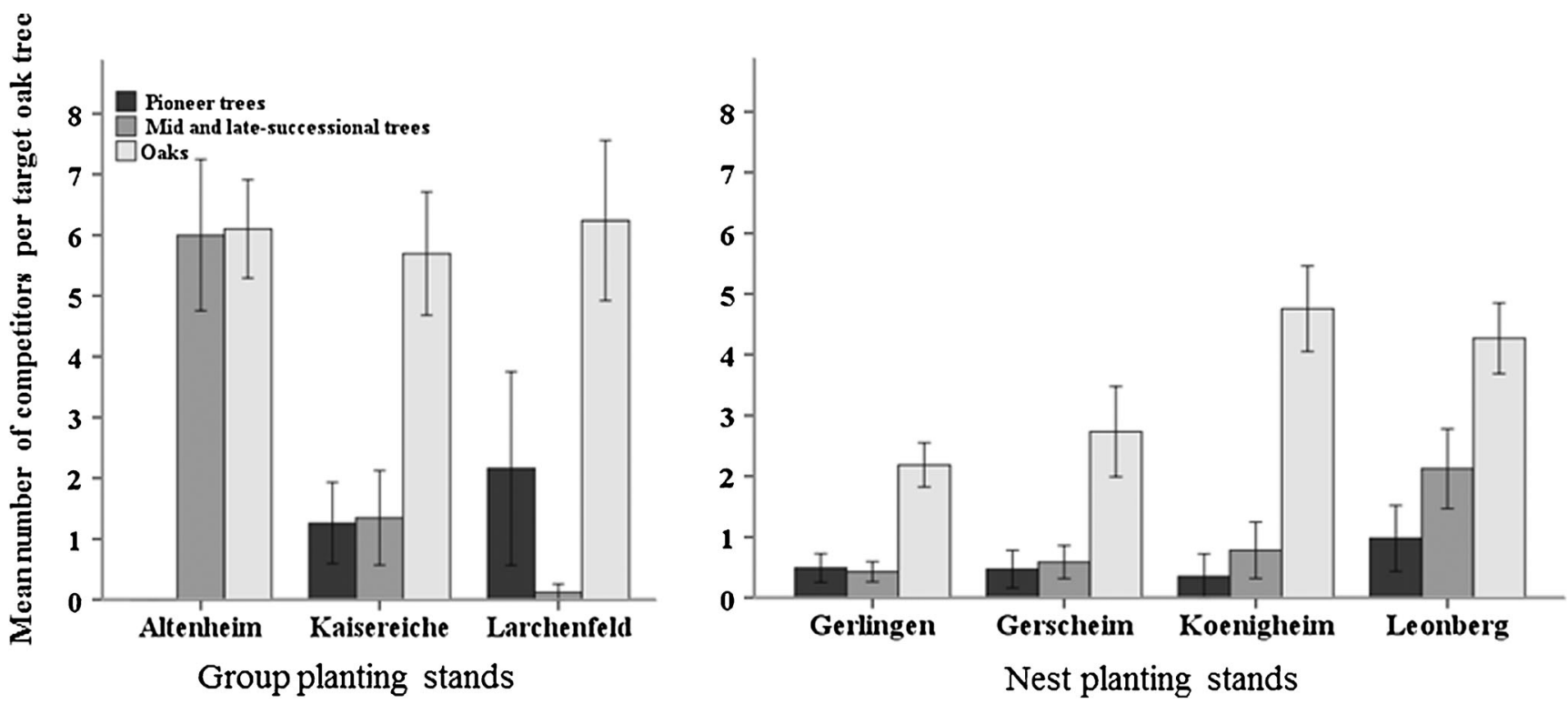

Fig. 1 Number of competing trees per target oaks in seven different stands of cluster planting. Thin bar represented a standard error of mean 
Table 5 Mean distance between target oaks and competing trees from different groups of species
S.E. standard error, $n . a$. not available

\begin{tabular}{|c|c|c|c|c|c|c|}
\hline \multirow[t]{3}{*}{ Site } & \multicolumn{6}{|c|}{ Type of competitors } \\
\hline & \multicolumn{2}{|c|}{ Competing oaks (m) } & \multicolumn{2}{|c|}{ Pioneer species (m) } & \multicolumn{2}{|c|}{ Mid- and late-successional species (m) } \\
\hline & Mean & S.E. & Mean & S.E. & Mean & S.E. \\
\hline Altenheim & 1.72 & 0.05 & n.a. & n.a. & 1.92 & 0.05 \\
\hline Kaisereiche & 1.87 & 0.05 & 2.08 & 0.14 & 2.27 & 0.09 \\
\hline Lerchenfeld & 1.84 & 0.05 & 2.1 & 0.08 & 2.23 & 0.52 \\
\hline Gerlingen & 1.03 & 0.04 & 2.63 & 0.08 & 2.4 & 0.11 \\
\hline Gerchsheim & 0.9 & 0.07 & 1.5 & 0.25 & 2.07 & 0.14 \\
\hline Königheim & 1.07 & 0.09 & 2.46 & 0.25 & 2.39 & 0.13 \\
\hline Leonberg & 1.06 & 0.03 & 1.76 & 0.12 & 2.03 & 0.06 \\
\hline
\end{tabular}

from trees of mid- and late-successional trees had a strong negative influence (higher GLM estimate) on DBH and height growth. However, only intraspecific competition had a significant positive effect on the length of the branch-free bole (Fig. 3b).

In addition, we found that in absolute terms (Hegyi's index), interspecific competition had a negative relationship with intraspecific competition. As the level of interspecific competition increases, the intraspecific competition decreases (Spearman's correlation $=-0.21, p<0.05 ; F$ value $=4.02, p<0.05, N=247$ ).

\subsection{Distribution of potential future crop trees within groups}

On average, $80 \%$ of the sampled groups had at least one and $50 \%$ of at least two trees that met the criteria for potential future crop trees. At the stand level, the number of potential
Fig. 2 Influence of neighbourhood competition on dependent variables: DBH, height, $\mathrm{HD}$ ratio and branch-free bole length of target oaks grown in four 22- to 26-year-old nest planting stands. Impact of aggregate competition was calculated from a separate generalized linear model (see Eq. 1 in 'Materials and methods' section) that combined all competitors irrespective of species and precluded additive effects of different plant groups. Impact of competition from conspecific oaks, pioneer and midand late-successional species was estimated as interaction effects on dependent variables in another model (see Eq. 2 in 'Materials and methods' section). Thin bars represent a standard error of parameter estimates and should not touch the zero line for a significant effect

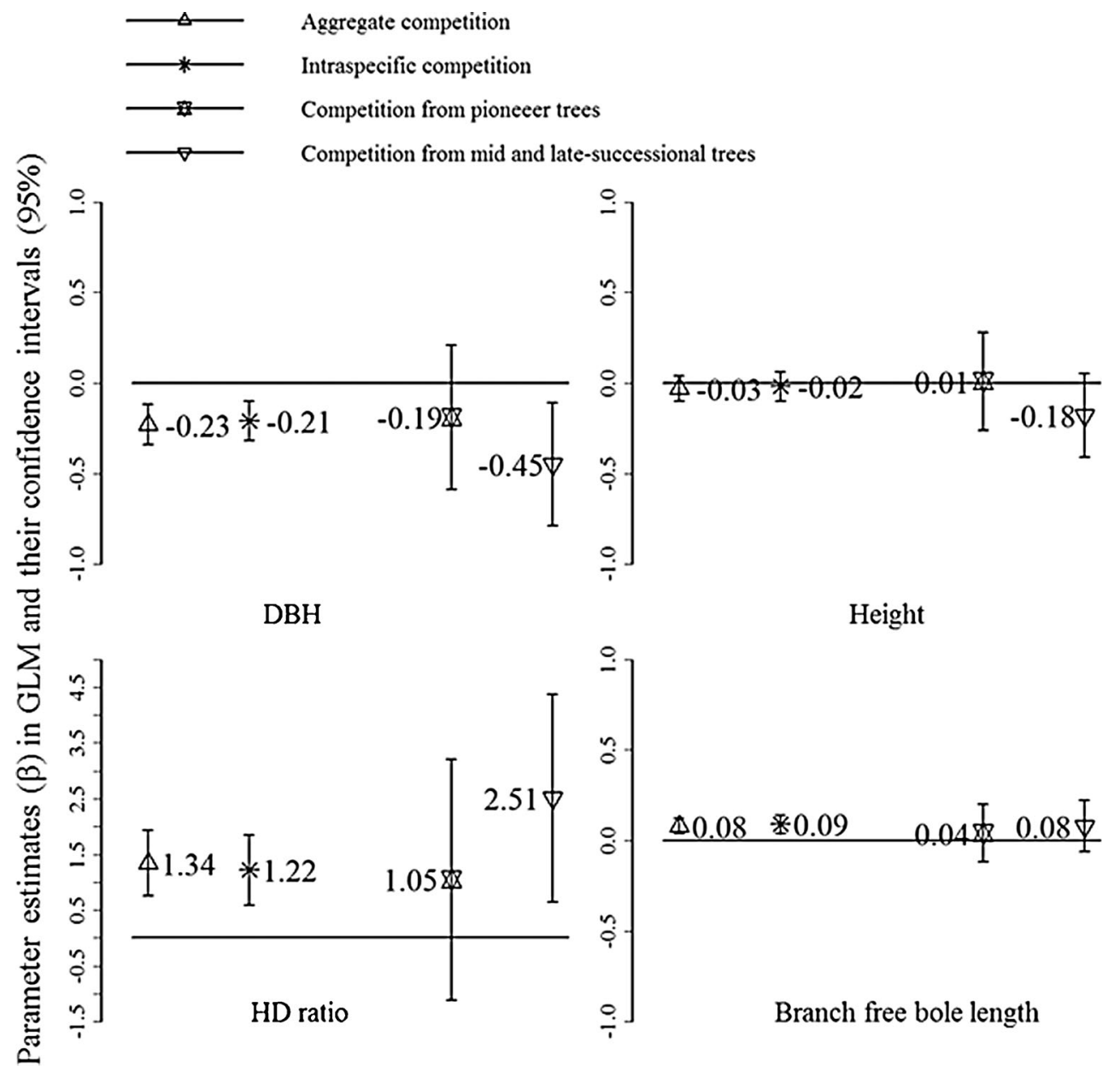




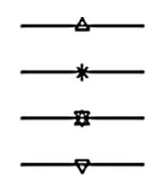

Aggregate competition

Intraspecific competition

Competition from pioneer trees

Competition from mid and late-successional trees

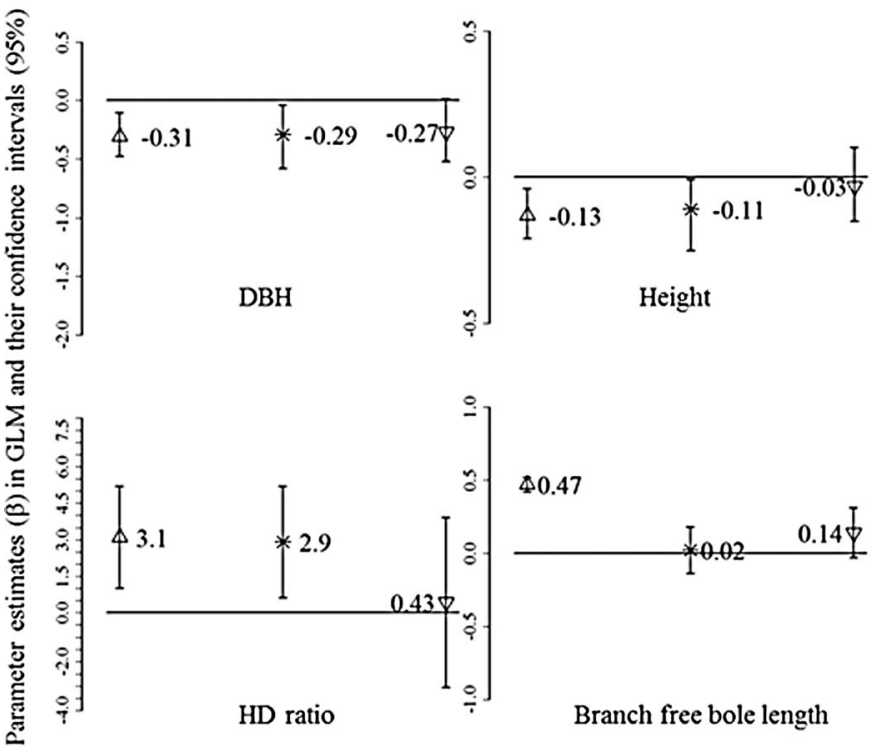

a

Fig. 3 Influence of neighbourhood competition on dependent variables: $\mathrm{DBH}$, height, HD ratio and branch-free bole length of target oaks grown in (a) one 10-year-old group planting stand (Altenheim) and (b) two 20year-old group planting stands. Impacts of aggregate competition and competition from different plant groups were separately calculated from

future crop trees amounted to a mean of 200 trees $^{-1} \mathrm{~h}^{-1}$. The majority (60\%) of these high-quality trees were located in the inner section of groups. This finding was corroborated by the logistic regression analysis, which revealed a significantly higher probability ( $\log$ odds ratio $=0.59, p=0.0014$ ) of occurrence for potential future crop trees in the inner section of groups than in the outer circle of trees (Table 6).

Using GLM analysis, we tested whether the influence of competitive interactions on attainment of branch-free bole length varied between potential future crop trees located either in the inner or outer sections of groups. Although not statistically significant $(p=0.114)$, intraspecific competition seemed to have a slightly positive influence (positive model estimate $\beta=0.12$ ) on branch-free bole length in potential future crop
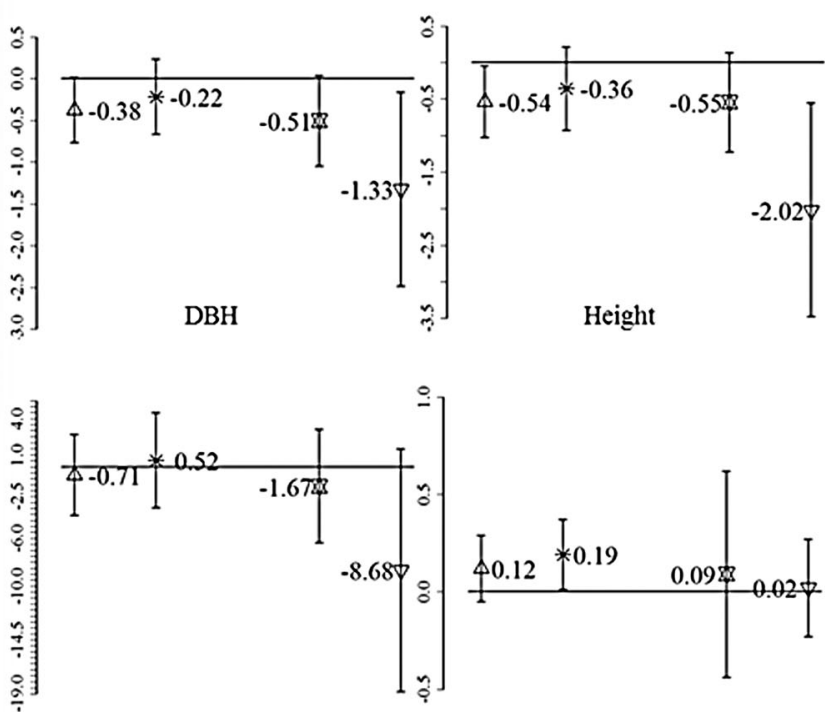

HD ratio

Branch free bole length

\section{b}

the Eqs. 1 and 2, respectively (see 'Materials and methods' section and description in Fig. 2). In Altenheim stand, no competitors were found from pioneer tree species. Thin bars represent a standard error of parameter estimates and should not touch the zero line for a significant effect

trees located in the inner section of groups. In addition, interspecific competition showed a significant negative effect on branch-free bole length on oaks in the outer section of groups (Table 7). Although not statistically significant $(p>0.05)$, competition from pioneer trees, conspecific oaks and aggregate competition was higher in inner oaks than in peripheral oaks, and competition from mid- and late-successional trees was lower in inner oaks than in outer oaks (Fig. 4).

\section{Discussion}

Our study showed that intra- and interspecific neighbourhood competition influenced growth and quality of oaks in nest and

Table 6 Influence of spatial location of oak trees within groups on the probability of occurrence of potential future crop trees (binary logistic regression analysis)

\begin{tabular}{|c|c|c|c|c|c|c|}
\hline Response variable & Predictors & $\beta$ & $\begin{array}{l}\text { S.E. } \\
\beta\end{array}$ & $\begin{array}{l}\text { Wald's } \\
\chi^{2}\end{array}$ & d.f. & Chi-square test \\
\hline \multirow{2}{*}{$\begin{array}{l}\text { Potential future crop tree } \\
\quad \text { (yes or no) }(N=1,098)\end{array}$} & Constant & -2.23 & 0.13 & 282.45 & 1 & \multirow[b]{2}{*}{$\chi^{2}=10.17, p=0.0014$} \\
\hline & $\begin{array}{l}\text { Position in group }(1=\text { inner section, } \\
2=\text { periphery) }\end{array}$ & 0.59 & 0.18 & 10.14 & 1 & \\
\hline
\end{tabular}

$\beta \log$ odd ratio, S.E. standard error in $95 \%$ confidence interval, $d . f$. degree of freedom 
Table 7 Influence of spatial location and type of competition on branchfree bole length in potential future crop trees in group plantings. Interaction terms were built between the type of competition and the location of target oak trees (inner section or periphery of groups) in two separate models for intra- and interspecific competitions, respectively. Number of target trees included for this analysis was 79 . Here, $\beta$ refers to model estimate in GLM. For a significant effect, upper or lower limit of the confidence interval for the standard error of $\beta$ should not reach 0

\begin{tabular}{|c|c|c|c|c|c|c|c|}
\hline \multirow[t]{2}{*}{ Independent variables } & \multirow{2}{*}{$\begin{array}{l}\text { Model } \\
\text { estimates } \\
(\beta)\end{array}$} & \multirow{2}{*}{$\begin{array}{l}\text { Standard } \\
\text { error of } \\
\beta\end{array}$} & \multicolumn{2}{|c|}{$\begin{array}{l}95 \% \text { Wald confidence } \\
\text { interval }\end{array}$} & \multirow[t]{2}{*}{$\begin{array}{l}\text { Wald } \chi^{2} \\
\text { value }\end{array}$} & \multirow[t]{2}{*}{ d.f. } & \multirow[t]{2}{*}{$p$ value } \\
\hline & & & Lower & Upper & & & \\
\hline Intercept & 4.0316 & 0.2862 & 3.4707 & 4.5925 & 198.4439 & 1 & 0.0000 \\
\hline Inner section $\times$ intraspecific competition & 0.1277 & 0.0808 & -0.0307 & 0.2860 & 2.4979 & 1 & 0.1140 \\
\hline Periphery $\times$ intraspecific competition & 0.0043 & 0.0959 & -0.1836 & 0.1921 & 0.0020 & 1 & 0.9645 \\
\hline Maximum likelihood estimate & 1.3460 & 0.2156 & 0.9835 & 1.8424 & & & \\
\hline Intercept & 4.5899 & 0.1905 & 4.2166 & 4.9632 & 580.7293 & 1 & 0.0000 \\
\hline Inner section $\times$ interspecific competition & -0.0388 & 0.0837 & -0.2028 & 0.1251 & 0.2153 & 1 & 0.6426 \\
\hline Periphery $\times$ interspecific competition & -0.3163 & 0.1011 & -0.5144 & -0.1182 & 9.7906 & 1 & 0.0018 \\
\hline Maximum likelihood estimate & 1.2500 & 0.2002 & 0.9135 & 1.7113 & & & \\
\hline
\end{tabular}

d.f. degree of freedom

group plantings in different ways. It appeared that growth of oaks was more strongly influenced by intraspecific competition in Altenheim group planting stand, whereas in two other stands, interspecific competition from mid- and latesuccessional species was most important. Whereas intraspecific competition had a significantly positive effect on branchfree bole length of target oaks in older nest and group plantings, similar effects of interspecific interactions on selfpruning were not observed.

4.1 Influence of neighbourhood competition on $\mathrm{DBH}$, height and HD ratio of potential future crop trees

The magnitude of neighbourhood competition on $\mathrm{DBH}$, height and HD ratio varied among conspecific oaks, pioneer and mid- and late-successional trees. This result is consistent with the first hypothesis. In our study, neighbourhood competition was quantified by Hegyi's index for conspecific oaks and trees from different successional groups. We assumed that similar competition indices from different plant species groups would result in different growth responses of target oak trees. In addition to tree size and distance, which are the parameters considered by the competition index, speciesspecific traits such as light absorption, light, water and nutrient use efficiency of species influence competition among trees (Binkley et al. 2013). Therefore, in cluster planting stands, which present variable mixtures of planted oaks and naturally regenerated pioneer and mid- and late-successional species, the same competition index may result in different responses of target oak trees.
Fig. 4 Comparison of competition indexes of potential future crop trees (target trees) in between inner and outer sections of groups divided in different successional groups $\left(N_{\text {inner }}\right.$ section $=44, N_{\text {outer section }}=34$; thin bars represent a standard error of mean at $95 \%$ confidence interval)

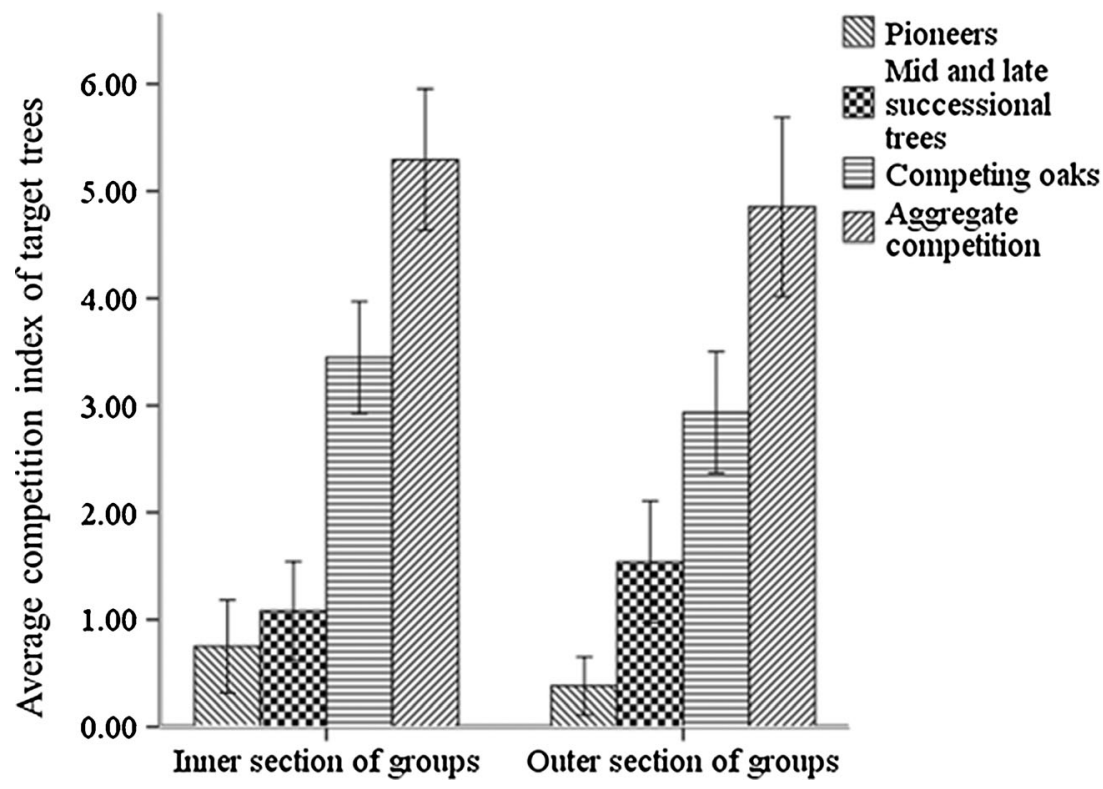




\subsubsection{Intraspecific competition}

Strong intraspecific competition between the closely planted oaks within the nests reduced diameter growth and resulted in more slender trees. The high HD ratios indicate that competition for light became intense and encouraged trees to allocate their resources to height growth rather than to diameter growth, in order to maintain their position in the canopy (Waring and Schlesinger 1985). This result is supported by a recent metaanalysis, which found poor tree stability in densely planted oak nests compared to more widely spaced oak row plantings (Saha et al. 2012). The impact of intraspecific competition on tree growth and stability appeared to be stronger in the young Altenheim stand than in older Kaisereiche and Lerchenfeld. The mean height of oaks growing in the 20-year-old submontane Kaisereiche stand was slightly lower than that in the 10-year-old bottomland Altenheim stand. Therefore, faster height growth at Altenheim might have led to earlier canopy closure and thus increased intraspecific competition. However, owing to the lack of replicates for these different ages, this assumption cannot be ascertained in this study.

Compared to the groups, intraspecific competition in nests was more intense, and mortality rates of planted oaks were greater, resulting in fewer trees per cluster over time (Leder 2007; Guericke et al. 2008; Saha et al. 2012). The resulting continuously high intraspecific competition inside nests strongly affected the DBH and stability of target oaks early on, as reported previously from oak spacing experiments (Gaul and Stüber 1996; Gürth and Velasquez 1991). The negative impact of intense intraspecific competition on the number of potential future crop trees in nests corroborates findings of a recent metaanalysis by Saha et al. 2012, which showed that the proportion of potential future crop tree was $80 \%$ lower in nests than in group and conventional row plantings, which held approximately 200 future crop trees $\mathrm{ha}^{-1}$.

\subsubsection{Interspecific competition}

The DBH of interspecific competitors neither varied between successional groups nor with target oaks; however, magnitude of competitive effects on target oaks varied between successional groups. The negligible influence of pioneer trees on DBH, height and tree stability observed in our results may have resulted from a lower density of such trees, a lower density of their crowns which permits more light to penetrate (Tonioli et al. 2001; McLeod et al. 2001). Results from previous studies in Central Europe showed that fast-growing early successional trees can exert a strong competition to oaks in young stands (Wagner and Röker 2000; Petersen et al. 2009; von Lüpke 1991; Ammer and Dingel 1997). In these studies, the neighbourhood competition from naturally regenerated pioneers on oak growth was quantified. Importantly, these analyses focussed only on pioneer trees like birch, aspen and willow and did not separate competition based on successional characteristics of competing tree species. However, in the case of cluster plantings, mixtures of naturally regenerated pioneers, mid- and late-successional trees and planted oaks occurred. Birch is commonly known as a strong competitor to oaks in young stands (Wagner and Röker 2000). Yet, whether its competitive effect is stronger than that of other pioneer tree species on oak growth has not been studied in a comparative way for the same site and stand conditions. Whether pioneer species like birch exerted a stronger competition when compared to other pioneers (e.g. willow or poplar) on oaks grown in clusters cannot be ascertained by this study because these species did not cover the same gradient of competitive influence at particular sites and across sites.

The mid- and late-successional species (e.g. T. cordata, C. betulus, A. pseudoplatanus, etc.) were often more numerous than individuals of pioneer species. This was reflected in lower average values for the competition index of pioneer species than mid- and late-successional species to target oaks located in inner and outer sections of group planting (see Fig. 4). The latter group of species obviously developed dense crowns and reduced light penetration to the middle and lower part of crowns of target oaks. This supports earlier observations that traditional trainer species (e.g. C. betulus or T. cordata) can reduce growth of oak trees if not controlled (von Lüpke 1998). As a result, the magnitude of the competitive influence from trees of mid- and late-successional species on DBH and height of target oaks in both nest and group plantings was substantially stronger than that of early successional species. Our results support previous studies on tree interactions in dense and young mixed species mixtures which showed stronger competitive effects on target trees by mid- and late-successional tree species than by pioneers (Leder 1996; Ammer et al. 2005). Interestingly, we found that the magnitude of impact by mid- and late-successional trees on target oaks was apparently higher than aggregate competition, which combined both intra- and interspecific competitions. This is counterintuitive and must be the result of including interactive effects between different tree species groups in our models, although the absolute value of aggregate competition was higher than competition from trees of mid- and late-successional species. Obviously, interactions between intra- and interspecific competitors reduced the overall competitive impact from aggregate competition on target oaks. Although an early tending operation of low intensity had removed some competitors at the periphery of groups in Gerlingen and Lerchenfeld, this may not have had a substantial influence on the overall magnitude of the different sources of competition. First, the tending operations did not target particular species for removal. Secondly, no early tending took 
place in other sites, where the same results were obtained. Third, regeneration of trees was abundant between the clusters, and the canopy was totally closed at the time of field data collection at all sites (Saha 2012, 2013).

In young stands, pedunculate and sessile oak can tolerate mild competition from pioneer tree species such as $B$. pendula or may even benefit from nurse effects such as reduced frost or improved nutrient cycling (Leder 1996; Rock et al. 2004). However, similar nursing effects on oaks have not been reported for mid- and late-successional tree species. By contrast, the influence of late-successional tree species such as $F$. sylvatica, $C$. betulus and A. pseudoplatanus on the growth of oaks appears to be mostly negative once these trees are as tall as oaks or overtop them (Olano et al. 2009; von Lüpke 1998). This is likely attributable to higher light interception and their more aggressive acquisition of growing space when compared to the early successional species (Pretzsch and Biber 2010).

4.2 Influence of neighbourhood competition on branch-free bole length of potential future crop trees

Aggregate neighbourhood competition did not influence branch-free bole length of potential future crop trees in the young group planting. In young groups, the canopies had only recently closed, and steep-angle branches emerging from the lower stem had not yet been shed. However, intraspecific competition promoted branch-free bole length of target oaks in older group and nest plantings. This is in partial agreement with our second hypothesis. Thus, companion oak trees have an important role for the qualitative development of future crop trees within clusters. Our study did not find a facilitative effect of interspecific competition on the quality of target oak trees. Results from a previous study according to which a sufficient number of naturally established trees between oak nests fostered the qualification of oaks could not be verified here (Dong et al. 2007). Why competition from neighbouring trees of mid- and late-successional species affected DBH and height growth without influencing self-pruning dynamics of oaks remains unclear. However, it is reflected in our results that potential future crop trees in the outer part of clusters, owing to the heterogeneous light conditions prevailing there, have a tendency to retain live branches in the lower parts of the stem. This finding supports an earlier assumption by Leder (2007) that oaks located in the periphery of clusters may develop one-sided crowns in the direction of open spaces between the clusters. Another remaining question, as to whether the function of intraspecific competition on the quality development of cluster oaks in low-density plantings could be assumed, at least in part, by interspecific competition, can be further evaluated through the analysis addressing the third hypothesis.
4.3 Influence of within-group position on occurrences of potential future crop trees

The higher probability of the occurrence of potential future crop trees in inner than in outer sections of groups is in agreement with the third hypothesis. Trees situated in the inner part of groups experienced mostly intraspecific competition, which has been shown to suffice for the desired crown lift and development of a branch-free lower bole (Fischer 2000). However, this result indicates that the quality development is restricted or slowed in oak trees that experience more interspecific than intraspecific competition (outer trees of groups). These trees received less aggregate competition when compared to trees experiencing mostly competition from conspecific oaks, because of low density of naturally regenerated competitors and variation in proportion of pioneer vs. midand late-successional trees. This suggests that there is little potential to reduce the number of trees in oak groups to replace outer trees with naturally regenerated trees.

\section{Conclusion and management implications}

This is the first study to provide quantitative support for the assumptions made by early proponents of cluster plantings that, owing to the prevalence of intraspecific competition, the improvement in stem quality of oak trees is better, or advances faster, in the inner part of group plantings than in the outer circle (Anderson 1930; Szymanski 1986; Gockel 1995). On the one hand, the spatial separation of oaks from pioneers and mid- and late-successional trees reduces the impact of interspecific competition. On the other hand, oaks in groups with $1 \mathrm{~m}^{2}$ of initial growing space per tree do not only protect each other from interspecific competition but also facilitate selfpruning dynamics and tree quality development. In contrast, very close spacing in nest plantings triggers high intraspecific competition leading to early mortality and, hence, the disintegration of nests. Based on this study and a recent study by Saha et al. 2012, we cannot recommend nest plantings, which may lead to poor growth and high mortality owing to intense intraspecific competition. However, group plantings (with ca. $1 \times 1 \mathrm{~m}$ initial spacing between the seedlings), where intraspecific competition had beneficial effects on oak growth can be recommended as an alternative to high-input row planting.

Additional interspecific competition did not offer advantages to the quality development of oaks but negatively affected height and diameter growth. Vigorous trees of early and mid-successional species growing inside or in close proximity of groups, thus, should be removed as part of early standtending operations. The decision to complement oak groups with trainer trees such as $T$. cordata, $C$. betulus and $F$. sylvatica should consider trade-offs between risks and benefits of trainer trees. On the one hand, they may affect growth of 
oaks as shown in our study. On the other hand, they can reduce competition to oaks from ground vegetation such as black berries, grasses, etc. and thus help to reduce oak mortality (Saha et al. 2012). Later in stand development, this cohort of shade-tolerant trees will help to suppress the development of epicormic branches in oaks. Thus, trainer trees are not dispensable. However, they may also regenerate naturally between and within clusters or, if not, may be planted at a later stage. In any case, the competition between trainer species and oaks needs to be monitored carefully and, if necessary, controlled through thinning or pollarding.

Acknowledgments The author gratefully acknowledges the receipt of a $\mathrm{PhD}$ scholarship from the German Academic Exchange Service (DAAD). We thank the State Forestry Administration of Rheinland-Pfalz, the Georg-Ludwig-Hartig Stiftung, and the Graduate School 'Environment, Society and Global Change' of Albert Ludwigs University of Freiburg for providing financial support. We are thankful to Prof. Dr. Ulrich Kohnle of the Forest Research Institute of Baden-Württemberg for providing valuable information on cluster planting trials. We thank Dr. David Forrester for providing comments and suggestions on a previous version of the manuscript and English corrections. We are also thankful to Ms. Charlotte Krebs who helped with field data collection and database preparation.

\section{References}

Ammer C, Dingel C (1997) Investigating the effects of strong competition by inferior tree species on growth and quality of young European oaks. Forstwiss Cent B1 116:346-358

Ammer C, Ziegler C, Knoke T (2005) Assessing intra- and interspecific competition in thickets of broadleaved tree species. Allg Forst Jagdztg 176:85-94

Anderson ML (1930) A new system of planting. Scott For J 44:78-89

Binkley D, Campoe OC, Gspaltl M, Forrester DI (2013) Light absorption and use efficiency in forests: why patterns differ for trees and stands. For Ecol Manag 288:5-13

Börner M, Guericke M, Leder B, Nutto L, Stähr F, Weinreich A (2003) Erhebung qualitätsrelevanter Parameter am EinzelbaumAufnahmestandards für junge bis mittelalte Laubhölzer als Grundlage für wissenschaftliche Untersuchungen. Forstarchiv 74:275-282

Brang P, Bürgi A (2004) Trupppflanzung im test. Zürcher Wald 36:13-16

Dong P.H., Eder W, Muth M (2007) Eichen-Nesterpflanzungsversuche in Rheinland-Pflaz-Ergebnisse eines $15 \mathrm{jährigen}$ Beobachtungszeitraums. Paper presented at the Eiche im Pfälzerwald, Trippstadt, Germany. http://www.wald-rlp.de/ fileadmin/website/fawfseiten/fawf/downloads/Mitteilungen/ Mitteilung-63_2007/Mitteilung-63_2007-2_Dong-EichenNesterpflanzungen.pdf. Accessed 21 Oct 2013

Drouineau S, Laroussinie O, Yves Birot, Terrasson D, Formery T, Roman-Amat B (2000) Joint evaluation of storms, forest vulnerability and their restoration. Discussion paper 9. European Forest Institute, Joensuu, Finland. ISBN: 952-9844-81-6

Ehring A, Keller O (2006) Eichen-Trupp-Pflanzung in BadenWürttemberg. AFZ/Der Wald 61:491-494

Fischer H (2000) Qualitätsverbesserung bei jungen Traubeneichen (Quercus petraea Liebl.) allein durch innerartliche Konkurrenz. Forst und Holz 55:377-382

Gauer J, Aldinger E (2005) Waldökologische Naturräume Deutschlands Forstliche Wuchsgebiete und Wuchsbezirke, mit Karte 1: 100.000.
Mitteilungen des Vereins für Forstliche Standortskunde und Forstpflanzenzüchtung. Freiburg i. Br. 43: p. 324

Gaul T, Stüber V (1996) Der Eichen-Nelder-Verbandsversuch Göhrde. Forst und Holz 51:70-75

Gea-Izquierdo G, Canellas I, Montero G (2008) Site index in agroforestry systems: age-dependent and age-independent dynamic diameter growth models for Quercus ilex in Iberian open oak woodlands. Can J For Res 38:101-113

Gockel H (1995) Die Trupp-Pflanzung, Ein neues Pflanzschema zur Begründung von Eichenbeständen. Forst und Holz 50:570-575

Guericke M, Petersen R, Blanke S (2008) Wachstum und Qualität von Eichennestern in Nordwestdeutschland. Forst und Holz 63:58-63

Gürth P, Velasquez C (1991) Qualitätsuntersuchungen an Eichenjungbeständen im Markgräflerland. Forst und Holz 46:671-677

Hegyi F (1974) A simulation model for managing Jack-pine stands. In: Fries J (ed) Growth models for tree and stand simulation, research notes $\mathrm{Nr}$ 30. Royal College of Forestry, Stockholm, pp 74-90

Kuehne C, Kublin E, Pyttel P, Bauhus J (2013) Growth and form of Quercus robur and Fraxinus excelsior respond distinctly different to initial growing space: results from 24-year-old Nelder experiments. J For Res 24:1-14

Leder B (1996) Weichlaubhölzer im Eichen- und Buchen-jungbeständen. Forst und Holz 51:340-344

Leder B (2007) Wachstum und qualitative Entwicklung von Eichennestern. AFZ/Der Wald 62:420-423

McCullagh P, Nelder J (1989) Generalized linear models. Chapman \& Hall/CRC, London

McLeod KW, Reed MR, Nelson EA (2001) Influence of a willow canopy on tree seedling establishment for wetland restoration. Wetlands 21 : 395-402

Olano JM, Laskurain NA, Escudero A, De La Cruz M (2009) Why and where do adult trees die in a young secondary temperate forest? The role of neighbourhood. Ann For Sci 66:105

Petersen R (2007) Eichen-Trupp-Pflanzung - erste Ergebnisse einer Versuchsfläche im NFA Neuhaus. Forst und Holz 62:19-25

Petersen R, Schüller S, Ammer C (2009) Early growth of planted pedunculate oak (Quercus petraea) in response to varying competition by birch (Betula pendula) over 8 years. Forstarchiv 80:208-214

Pretzsch H, Biber P (2010) Size-symmetric versus size-asymmetric competition and growth partitioning among trees in forest stands along an ecological gradient in central Europe. Can J For Res 40: 370-384

R Development Core Team (2011) R: a language and environment for statistical computing, 2.14.0 edn. R Foundation for Statistical Computing, Vienna

Rock J, Puettmann KJ, Gockel HA, Schulte A (2004) Spatial aspects of the influence of silver birch (Betula pendula L.) on growth and quality of young oaks (Quercus spp.) in central Germany. Forestry 77:235-247

Röhrig E, Bartsch N, Lüpke vB (2006) Waldbau auf ökologischer Grundlage. Eugen Ulmer, Stuttgart

Saha S (2012) Development of tree quality, productivity, and diversity in oak (Quercus robur and Q. petraea) stands established by cluster planting. Dissertation, Albert Ludwigs University of Freiburg

Saha S, Kuehne C, Kohnle U, Brang P, Ehring A, Geisel J, Leder B, Muth M, Petersen R, Peter J, Ruhm W, Bauhus J (2012) Growth and quality of young oaks (Quercus robur and Q. petraea) grown in cluster plantings in central Europe: a weighted meta-analysis. For Ecol Manag 283:106-118

Saha S, Kuehne C, Bauhus J (2013) Tree species richness and stand productivity in low-density cluster plantings with oaks (Quercus robur L. and $Q$. petraea (Mattuschka) Liebl.). Forests 4:650-665

Swanson ME, Franklin JF, Beschta RL, Crisafulli CM, DellaSala DA, Hutto RL, Lindenmayer DB, Swanson FJ (2010) The forgotten 
stage of forest succession: early-successional ecosystems on forest sites. Front Ecol Environ 9:117-125

Szymanski S (1986) Die Begründung von Eichenbeständen in "NestKulturen". Forst- und Holz 41:3-7

Tonioli M, Escarre J, Lepart J, Speranza M (2001) Facilitation and competition affecting the regeneration of Quercus pubescens Willd. Ecoscience 8:381-391

von Lüpke B (1991) Einfluss der Konkurrenz von Weichlaubholz auf das Wachstum junger Traubeneichen. Forst und Holz 46:166-171 von Lüpke B (1998) Silvicultural methods of oak regeneration with special respect to shade tolerant mixed species. For Ecol Manag 106:19-26

Wagner S, Röker B (2000) Birkenanflug in Stieleichenkulturen. Untersuchungen zur Dynamik der Konkurrenz über 5 Vegetationsperioden. Forst und Holz 55:18-22

Waring RH, Schlesinger WH (1985) Forest ecosystems: concepts and management. Academic, Florida

Wykoff WR (1990) A basal area increment model for individual conifers in the northern Rocky-mountains. For Sci 36:1077-1104 